\title{
Liraglutide in the treatment of heart failure: insight from FIGHT and LIVE
}

\author{
Bo Liang ${ }^{1}$ id and Ning Gu ${ }^{2^{*}}$ (B)
}

\begin{abstract}
There are many glucose-lowering agents used in patients with heart failure, showing mixed results, this study was conducted to determine the effect of liraglutide, a glucagon-like peptide-1 analogue, on the treatment of patients with heart failure. Patients from the FIGHT and LIVE trials were included, all overlapped data were summarized and described. No significant changes from baseline in left ventricular ejection fraction, $\mathrm{N}$-terminal pro-B-type natriuretic peptide, hemoglobin A1c, heart rate, left ventricular end-systolic volume index, left ventricular end-diastolic volume index, and 6 min walk test were observed in FIGHT. In LIVE, liraglutide significantly decreased hemoglobin A1c and inceased 6 min walk test and increased heart rate and serious cardiac adverse events, and there were no statistical differences in left ventricular ejection fraction, $\mathrm{N}$-terminal pro-B-type natriuretic peptide, left ventricular end-systolic volume index, and left ventricular end-diastolic volume index. In this study, we found that there is not enough reason to support the use of liraglutide in patients with heart failure, and importantly, the safety of liraglutide in this particular population remains uncertain. Enhanced recognition the risks and benefits of liraglutide would help guide therapeutic decisions in patients with heart failure.
\end{abstract}

Keyword: Glucagon-like peptide-1, Liraglutide, Heart failure, FIGHT, LIVE

Heart failure (HF) affects at least 26 million people worldwide, and the prevalence is increasing year by year. HF patients experience a high burden of symptoms and functional limitations, and morbidity and mortality remain high despite successful therapies [1]. Type 2 diabetes mellitus (T2DM), the most frequent subtype of diabetes, is an expanding global health problem [2], and in the past decades, the global prevalence has increased by $30 \%$, and now about 463 million people are affected. Both HF and T2DM independently increase the morbidity of another disease and associated with considerable mortality $[3,4]$. There are many glucose-lowering agents used in patients with HF [5], however, the results are mixed [6]. Here, we critically and systematically explored the effect

*Correspondence: 20193122@njucm.edu.cn; jsguning@163.com.edu.cn

${ }^{2}$ Nanjing Hospital of Chinese Medicine Affiliated to Nanjing University of Chinese Medicine, Nanjing, China

Full list of author information is available at the end of the article of liraglutide, a glucagon-like peptide-1 (GLP-1) analogue, on the treatment of patients with HF.

We included all perticipants from the Functional Impact of GLP-1 for Heart Failure Treatmen (FIGHT) [7] and Effect of Liraglutide on Left Ventricular Function in Stable Chronic Heart Failure Patients with and without Diabetes (LIVE) [8] trials, which are multicentre, double-blind, randomised, placebo-controlled clinical trial. Two reviewers extracted data independently and crossed check. Only data indicators from both trials can be used for subsequent analysis. All the results were descriptive analysis.

In those trials, 541 perticipants from 24 sites in the United States and 4 Danish Centres were included. The baseline of two trials was basically similar, regardless of general data, functional measures, physical examination, medical history, laboratory measures, echocardiographic data, and HF medications (Table 1). The outcomes of FIGHT and LIVE are not exactly the same, and we choose the coincident indicators for analysis. In FIGHT,

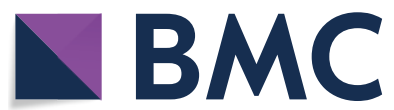

(c) The Author(s) 2020. This article is licensed under a Creative Commons Attribution 4.0 International License, which permits use, sharing, adaptation, distribution and reproduction in any medium or format, as long as you give appropriate credit to the original author(s) and the source, provide a link to the Creative Commons licence, and indicate if changes were made. The images or other third party material in this article are included in the article's Creative Commons licence, unless indicated otherwise in a credit line to the material. If material is not included in the article's Creative Commons licence and your intended use is not permitted by statutory regulation or exceeds the permitted use, you will need to obtain permission directly from the copyright holder. To view a copy of this licence, visit http://creativeco mmons.org/licenses/by/4.0/. The Creative Commons Public Domain Dedication waiver (http://creativecommons.org/publicdomain/ zero/1.0/) applies to the data made available in this article, unless otherwise stated in a credit line to the data. 
Table 1 The details of FIGHT and LIVE trials

\begin{tabular}{|c|c|c|c|c|}
\hline & \multicolumn{2}{|l|}{ FIGHT } & \multicolumn{2}{|l|}{ LIVE } \\
\hline & Liraglutide $(\mathrm{N}=154)$ & Placebo $(N=146)$ & Liraglutide $(\mathrm{N}=122)$ & Placebo $(\mathrm{N}=119)$ \\
\hline \multicolumn{5}{|l|}{ Genaral data } \\
\hline Age & $62(52-68)$ & $61(51-67)$ & $65 \pm 9.2$ & $65 \pm 10.7$ \\
\hline Male & $123(80 \%)$ & $113(77 \%)$ & 109 (89\%) & 106 (89\%) \\
\hline $\mathrm{BMI}\left(\mathrm{kg} / \mathrm{m}^{2}\right)$ & $31(26-36)$ & $33(25-38)$ & $28.0 \pm 3.8$ & $29.8 \pm 4.6$ \\
\hline \multicolumn{5}{|l|}{ Functional measures } \\
\hline $6 \mathrm{MWT}(\mathrm{m})$ & $234(143-313)$ & $212(141-311)$ & $453 \pm 104$ & $441 \pm 122$ \\
\hline \multicolumn{5}{|l|}{ NYHA } \\
\hline I & $4(3 \%)$ & $8(5 \%)$ & $36(30 \%)$ & $35(29 \%)$ \\
\hline$\|$ & $49(32 \%)$ & $36(25 \%)$ & $65(53 \%)$ & $64(54 \%)$ \\
\hline III & $93(60 \%)$ & $96(66 \%)$ & $17(14 \%)$ & $16(13 \%)$ \\
\hline IV & $8(5 \%)$ & $6(4 \%)$ & $4(3 \%)$ & $4(3 \%)$ \\
\hline \multicolumn{5}{|l|}{ Physical examination } \\
\hline SBP & $108(99-120)$ & $108(99-118)$ & $128 \pm 20$ & $127 \pm 18$ \\
\hline $\mathrm{HR}$ & $75(68-85)$ & $76(68-88)$ & $67 \pm 10$ & $67 \pm 11$ \\
\hline \multicolumn{5}{|l|}{ Medical history } \\
\hline $\mathrm{T} 2 \mathrm{DM}$ & $91(59 \%)$ & $87(60 \%)$ & $39(32 \%)$ & $35(29 \%)$ \\
\hline $\mathrm{AF}$ & 74 (48\%) & $70(48 \%)$ & $34(28 \%)$ & $34(29 \%)$ \\
\hline Ischemic heart disease & $133(86 \%)$ & $113(77 \%)$ & $72(59 \%)$ & $73(61 \%)$ \\
\hline \multicolumn{5}{|l|}{ Laboratory measures } \\
\hline NT-proBNP (pg/mL) & $1936(1075-4231)$ & $2083(1020-4333)$ & $413(208-926)$ & $388(153-880)$ \\
\hline $\mathrm{HbA1c}(\%)$ & $6.6(6.6-7.6)$ & $6.7(5.9-7.9)$ & $5.9 \pm 0.7$ & $6.0 \pm 0.8$ \\
\hline \multicolumn{5}{|l|}{ Echocardiographic data } \\
\hline LVEF (\%) & $25(20-33)$ & $25(19-32)$ & $33.7 \pm 7.6$ & $35.4 \pm 9.4$ \\
\hline LVESV (mL) & $104(78-130)$ & $100(80-1330$ & $111 \pm 60$ & $109 \pm 78$ \\
\hline LVEDV (mL) & $140(112-173)$ & $137(115-174)$ & $163 \pm 71$ & $165 \pm 111$ \\
\hline$E / e^{\prime}$ & $22(17-28)$ & $23(18-30)$ & $12.6 \pm 6.0$ & $11.7 \pm 5.5$ \\
\hline \multicolumn{5}{|l|}{ Heart failure medications } \\
\hline ACEI/ARB & $112(73 \%)$ & 104 (71\%) & 118 (97\%) & 115 (97\%) \\
\hline$\beta$-Blocker & $143(93 \%)$ & $139(95 \%)$ & $113(93 \%)$ & $108(91 \%)$ \\
\hline Aldosterone recepter antagonist & $88(57 \%)$ & 89 (61\%) & $59(48 \%)$ & $54(45 \%)$ \\
\hline Loop diuretic & $151(98 \%)$ & $146(100 \%)$ & $90(74 \%)$ & $90(76 \%)$ \\
\hline Lipid-lowering agent & $110(71 \%)$ & $110(75 \%)$ & $96(79 \%)$ & $92(77 \%)$ \\
\hline \multicolumn{5}{|l|}{ Treatmen effect } \\
\hline LVEF & $-0.1(-2.3-2.1)$ & & $-0.8(-2.1-0.5)$ & \\
\hline LVESV & $5(-2.6-12.7)$ & & $2.6(-1.2-6.4)$ & \\
\hline LVEDV & $6.7(-2.6-16)$ & & $3.4(-2.3-9.2)$ & \\
\hline $6 \mathrm{MWT}$ & $5(-29-39)$ & & $24(2-47)$ & \\
\hline NT-proBNP (pg/mL) & $-155(-1368-1058)$ & & $-140(-317-37)$ & \\
\hline $\mathrm{HbA} 1 \mathrm{c}(\%)$ & $-0.33(-0.67-0)$ & & $-0.4(-0.5--0.3)$ & \\
\hline $\mathrm{HR}$ & $-1.6(-4.8-1.6)$ & & $7(5-9)$ & \\
\hline
\end{tabular}

FIGHT Functional Impact of GLP-1 for Heart Failure Treatmen, LIVE Effect of Liraglutide on Left Ventricular Function in Stable Chronic Heart Failure Patients with and without Diabetes, BMI body mass index, 6MWT 6-min walk test, NYHA New York Heart Association, SBP systolic blood pressure, HR heart rate, T2DM type 2 diabetes mellitus, AF atrial fibrillation, NT-proBNP N-terminal pro-B-type natriuretic peptide, $H b A 1$ chemoglobin A1c, LVEF left ventricular ejection fraction, $L V E S V$ left ventricular end-systolic volume index, LVEDV left ventricular end-diastolic volume index, E/e' ratio of early mitral inflow velocity to early diastolic medial mitral annular velocity, $A C E l$ angiotensin-converting enzyme inhibitor, $A R B$ angiotensin receptor blocker

liraglutide decreased left ventricular ejection fraction, N-terminal pro-B-type natriuretic peptide, hemoglobin A1c and heart rate, and increased left ventricular end-systolic volume index, left ventricular end-diastolic volume index, and 6 min walk test, compared with placebo. However, there was no statistical difference. In 
LIVE, liraglutide significantly decreased hemoglobin A1c $(P<0.0001)$ and inceased 6 min walk test $(P=0.04)$ and heart rate $(P<0.0001)$, compared with placebo. There were no statistical differences in the influence of the abovementioned outcomes that coincided with FIGHT (Table 1).

In LEADER, the rate of the primary composite outcome in the time-to-event analysis (the first occurrence of death from cardiovascular causes, nonfatal myocardial infarction or nonfatal stroke) among patients with T2DM and high cardiovascular risk was lower with liraglutide than with placebo, whereas the number of hospitaion for HF was reduced non-significantly in the active arm [9]. The encouraging results of this study may only indicate the potential strong benefits of liraglutide for diabetic patients with high cardiovascular risk. In our study, we specifically included patients with demonstrated HF, not with high cardiovascular risk, to evaluate the effectiveness and safety of liraglutide, and we concluded that liraglutide may be helpful for patients with HF. After careful investigation, we found that the results of FIGHT and LIVE were not identical. The reasons may be various. Firstly, the prescription of liraglutide is different. Liraglutide dosage uptitration as tolerated every 14 days from 0.6 to 1.2 to $1.8 \mathrm{mg} / \mathrm{d}$ during the first 30 days of the FIGHT trial, whereas subcutaneous injectable liraglutide was introduced at a dose of $0.6 \mathrm{mg} / \mathrm{day}$, which was increased to $1.2 \mathrm{mg} /$ day after 1 week and to $1.8 \mathrm{mg}$ /day thereafter in the LIVE trial. Although a dose increase could be postponed depending on the patient's tolerance to the trial product or reduced at any time during the trial if required, different administration of liraglutide may also have an impact on the results. For later trials, we may need a unified way of liraglutide dosing. The second may be recommended because it is consistent with LEADER $[9,10]$. Secondly, though HF with left ventricular ejection fraction $<45 \%$ was included, it was clear that the degree of HF in FIGHT was more severe than that in LIVE, because it was dominated by New York Heart Association Class II and III (90\%). Additionally, two studies were conducted in different country, which may result in excursion in race. Finally, results from LIVE indicated that treatment with liraglutide was associated with an increase in heart rate and more serious cardiac adverse events. More data on the safety of liraglutide in patients with HF are needed.

In this study, we found that there is not enough reason to support the use of liraglutide in patients with HF, which is consistent with the latest updated meta-analysis of 43 randomized controlled trials [11]. Another a network meta-analysis of 171,253 participants from 91 randomized controlled trials also showed that GLP-1 analogue was significantly inferior to sodium-glucose co-transporters 2 inhibitors in terms of HF risk [12]. Among patients with HF and T2DM, after adjusting for baseline characteristics and disease risk factors, the use of GLP-1 analogue was associated with higher risk of HF hospitalization compared to dipeptidyl peptidase- 4 inhibitors, though the association was not statistically significant [13]. In the spontaneously developed HF model of J2N-k hamsters, liraglutide exerted further deteriorated cardiac function with overt fibrosis and cardiac enlargement [14]. However, clinical evidences showed that liraglutide reduced early left ventricular diastolic filling and left ventricular filling pressure, thereby unloading the left ventricle $[15,16]$. Renal dysfunction is often associated with HF. Interestingly, liraglutide was not associated with excess risk of worsening renal function compared with placebo [17], result from post hoc analysis of FIGHT, supporting the relative renal safety profile of liraglutide among patients with HF. Additionaly, GLP-1 analogue reveals cardiovascular and renal protective effects, although this effect is not as evident as sodium-glucose co-transporters 2 inhibitor $[18,19]$.

In summary, the results of the body of existing evidence do not support the use of liraglutide in HF. Importantly, the safety of liraglutide in this particular population remains uncertain. Therefore, further studies are needed to assess the risks and benefits of liraglutide in patients with HF.

\section{Abbreviations \\ FIGHT: Functional Impact of GLP-1 for Heart Failure Treatmen; GLP-1: Glucagon-like peptide-1; HF: Heart failure; LIVE: Effect of Liraglutide on Left Ventricular Function in Stable Chronic Heart Failure Patients with and without Diabetes; T2DM: Type 2 diabetes mellitus.}

\section{Acknowledgements}

We thank all scientists and participants involved in the FIGHT and LIVE trials.

\section{Authors' contributions}

Both authors researched data for the article, discussed its content, wrote the manuscript, and reviewed and edited it before submission. Both authors read and approved the final manuscript.

\section{Funding}

None.

Availability of data and materials

Not applicable.

Ethics approval and consent to participate

Not applicable.

Consent for publication

Not applicable.

Competing interests

The authors declare that they have no competing interests. 


\begin{abstract}
Author details
${ }^{1}$ Nanjing University of Chinese Medicine, Nanjing, China. ${ }^{2}$ Nanjing Hospital of Chinese Medicine Affiliated to Nanjing University of Chinese Medicine, Nanjing, China.
\end{abstract}

Received: 29 May 2020 Accepted: 2 July 2020

Published online: 06 July 2020

\section{References}

1. Fiuzat M, Lowy N, Stockbridge N, Sbolli M, Latta F, Lindenfeld J, Lewis EF, Abraham WT, Teerlink J, Walsh M, et al. Endpoints in heart failure drug development: history and future. JACC Heart Fail. 2020;8(6):429-40.

2. Defronzo RA, Ferrannini E, Groop L, Henry RR, Weiss R. Type 2 diabetes mellitus. Nat Rev Disease Primers. 2015;1(41):15019.

3. Seferović PM, Coats AJS, Ponikowski P, Filippatos G, Huelsmann M, Jhund PS, Polovina MM, Komajda M, Seferović J, Sari I, et al. European Society of Cardiology/Heart Failure Association position paper on the role and safety of new glucose-lowering drugs in patients with heart failure. Eur J Heart Fail. 2020;22(2):196-21313.

4. McHugh K, DeVore AD, Wu J, Matsouaka RA, Fonarow GC, Heidenreich PA, Yancy CW, Green JB, Altman N, Hernandez AF. Heart failure with preserved ejection fraction and diabetes: JACC state-of-the-art review. J Am Coll Cardiol. 2019;73(5):602-11.

5. Liang B, Zhao Y-X, Zhang X-X, Liao H-L, Gu N. Reappraisal on pharmacological and mechanical treatments of heart failure. Cardiovasc Diabetol. 2020;19(1):55

6. Scheen AJ. GLP-1 receptor agonists and heart failure in diabetes. Diabetes Metab. 2017;43(Suppl 1):2S13-9.

7. Margulies KB, Hernandez AF, Redfield MM, Givertz MM, Oliveira GH, Cole R, Mann DL, Whellan DJ, Kiernan MS, Felker GM, et al. Effects of liraglutide on clinical stability among patients with advanced heart failure and reduced ejection fraction: a randomized clinical trial. JAMA. 2016:316(5):500-8.

8. Jorsal A, Kistorp C, Holmager P, Tougaard RS, Nielsen R, Hänselmann A, Nilsson B, Møller JE, Hjort J, Rasmussen J, et al. Effect of liraglutide, a glucagon-like peptide-1 analogue, on left ventricular function in stable chronic heart failure patients with and without diabetes (LIVE)-a multicentre, double-blind, randomised, placebo-controlled trial. Eur J Heart Fail. 2017;19(1):69-77.

9. Marso SP, Daniels GH, Brown-Frandsen K, Kristensen P, Mann JFE, Nauck MA, Nissen SE, Pocock S, Poulter NR, Ravn LS, et al. Liraglutide and cardiovascular outcomes in type 2 diabetes. N Engl J Med. 2016;375(4):311-22.

10. Marso SP, Poulter NR, Nissen SE, Nauck MA, Zinman B, Daniels GH, Pocock S, Steinberg WM, Bergenstal RM, Mann JFE, et al. Design of the liraglutide effect and action in diabetes: evaluation of cardiovascular outcome results (LEADER) trial. Am Heart J. 2013;166(5):823-30.

11. Nreu B, Dicembrini I, Tinti F, Sesti G, Mannucci E, Monami M. Major cardiovascular events, heart failure, and atrial fibrillation in patients treated with glucagon-like peptide-1 receptor agonists: an updated meta-analysis of randomized controlled trials. Nutr Metab Cardiovas. 2020;30(7):1106-1114.

12. Yang D-Y, He X, Liang H-W, Zhang S-Z, Zhong X-B, Luo C-F, Du Z-M, He J-G, Zhuang X-D, Liao X-X. Comparative outcomes of heart failure among existent classes of anti-diabetic agents: a network meta-analysis of 171,253 participants from 91 randomized controlled trials. Cardiovasc Diabetol. 2019;18(1):47.

13. Dawwas GK, Smith SM, Park H. Risk of heart failure hospitalization among users of dipeptidyl peptidase-4 inhibitors compared to glucagon-like peptide-1 receptor agonists. Cardiovasc Diabetol. 2018;17(1):102.

14. Shiraki A, Oyama J-I, Nishikido T, Node K. GLP-1 analog liraglutideinduced cardiac dysfunction due to energetic starvation in heart failure with non-diabetic dilated cardiomyopathy. Cardiovasc Diabetol. 2019;18(1):164.

15. Bizino MB, Jazet IM, Westenberg JJM, van Eyk HJ, Paiman EHM, Smit JWA, Lamb HJ. Effect of liraglutide on cardiac function in patients with type 2 diabetes mellitus: randomized placebo-controlled trial. Cardiovasc Diabetol. 2019;18(1):55.

16. Zhang D-P, Xu L, Wang L-F, Wang H-J, Jiang F. Effects of antidiabetic drugs on left ventricular function/dysfunction: a systematic review and network meta-analysis. Cardiovasc Diabetol. 2020;19(1):10.

17. Redouane B, Greene SJ, Fudim M, Vaduganathan M, Ambrosy AP, Sun $J$-L, DeVore AD, McNulty SE, Mentz RJ, Hernandez AF, et al. Effects of liraglutide on worsening renal function among patients with heart failure with reduced ejection fraction: insights from the FIGHT trial. Circ Heart Fail. 2020;13(5):e006758.

18. Fei Y, Tsoi M-F, Cheung BMY. Cardiovascular outcomes in trials of new antidiabetic drug classes: a network meta-analysis. Cardiovasc Diabetol. 2019;18(1):112.

19. Zelniker TA, Wiviott SD, Raz I, Im K, Goodrich EL, Furtado RHM, Bonaca MP, Mosenzon O, Kato ET, Cahn A, et al. Comparison of the effects of glucagon-like peptide receptor agonists and sodium-glucose cotransporter 2 inhibitors for prevention of major adverse cardiovascular and renal outcomes in type 2 diabetes mellitus. Circulation. 2019;139(17):2022-31.

\section{Publisher's Note}

Springer Nature remains neutral with regard to jurisdictional claims in published maps and institutional affiliations.
Ready to submit your research? Choose BMC and benefit from:

- fast, convenient online submission

- thorough peer review by experienced researchers in your field

- rapid publication on acceptance

- support for research data, including large and complex data types

- gold Open Access which fosters wider collaboration and increased citations

- maximum visibility for your research: over $100 \mathrm{M}$ website views per year

At BMC, research is always in progress.

Learn more biomedcentral.com/submissions 